\title{
Nanotechnology Development and Transference in the International Trade Law and the Intellectual Property Rights
}

\author{
Shila Taheri ${ }^{1}$ \\ ${ }^{1}$ Department of Law, Law Faculty, Islamic Azad University-Damghan Branch, Damghan, Iran \\ Correspondence: Shila Taheri, Department of Law, Law Faculty, Islamic Azad University-Damghan Branch, \\ Damghan, Iran. E-mail: shamyshila@gmail.com
}

Received: September 4, 2016

Accepted: October 2, 2016 Online Published: December 29, 2016

doi:10.5539/jpl.v10n1p155

URL: http://dx.doi.org/10.5539/jpl.v10n1p155

\begin{abstract}
The preset essay analyzes the nanotechnology development and transference in the international trade law and the intellectual property rights by implementing descriptive analytic method. The research findings show that determining the role and position and the function of intellectual property systems within the modern nanotechnology intellectual property at the international scenery and analyzing the plans and codifying policies and special protective programs in terms of development and enhancement of intellectual property in this technology and comprehensive approaches in support of the international intellectual property and change and correction of the organizational offices of nano patents registration is a critical issue. Codifying coordinated regulations for University research centers to ensure the unity of the researchers, lack of definite and fixed output for commercializing, study of the increasing mass of the number of registered patents, rise of the complexity of the patents (interdisciplinary patents) that lead to the limitations for the innovators in obtaining intellectual property rights, lack of the cooperation of the developing countries because of the obstacles of registering patents and being bereft of the benefits of nano because of the high expenses of registering the patents and the administration guarantee of the international documents are among the legal challenges of the intellectual property in nanotechnology.
\end{abstract}

Keywords: nanotechnology, invention, investment, industry development

\section{Introduction}

Today the power lies in nanotechnology and military facilities are no more the cause of obtaining power. There is a new wave in industrial countries to obtain the nanotechnology, whose main reason is to obtain power in the world. Nanotechnology is so important that scientific references refer to it as the fifth industrial revolution. State investments in nanotechnology and the sciences have increased three times between1997-2001 (Kalantari Meibodi, 2014). On the basis of the state reports of the United States of America and European countries the rate of the world investment in terms of nanotechnology research and development over a year has increased nine times and has reached from 200 million dollars in 1997 to 4/1 billion dollars in 2005. In Asia there are developmental programs in Japan, China, South Korea, Taiwan and Singapour and several important international agreements have increased in this respect. For example, agreements between the national foundation of science of America, European Union, APEC, Russia, and China and the states of New York and Cebeck of Canada have been signed (Shahmohammadi , 2014).

The majority of the nanotechnology centers is established in recent years. In addition to the digital revolution and the modern biology, nanotechnology as a key science and technology process have been attended and more inventions have occurred in this domain compared to the first two areas.

But one of the issues ahead of the nanotechnology is its statement through the legal intellectual property. The main problem lies in reaching an internationally unanimous consensus to obtain intellectual property rights in new technologies while the benefits of the different countries can lead to the lack of equilibrium in intellectual property rights. On the one hand the significance of intellectual property at the international level is on the rise so that intellectual properties have a pivotal role in commercial trades at international level and intellectual properties are now one of the most valuable capitals to be traded on the other hand nanotechnology (or any other type of technology) cannot be established bereft of legal requirements (Van calster, 2006). In this situation the main question is whether the definition of modern technology within the intellectual property is possible or not? 
Besides that, are present rules able to respond to the definition of nanotechnology? The present study in line with these issues first analyzes the nanotechnology and the intellectual property rights and then defines the position of nanotechnology position and its trade within the present rules while referring to the deficiencies.

\section{Concepts}

\subsection{Nanotechnology}

Nanotechnology or the second industrial revolution of the world is no rival for other technologies, but rather a complement and basis for them. This science, in fact, is the most significant economic potential of the twenty first century. Nanotechnology is a new science to eliminate the damages inflicted by the artificial sciences on today's world and convert the world into a paradise in a natural way so that the life gets more comfortable and pleasant for all people from young to old and satiate the hungry and eliminate famine and we witness many things that we cannot dream them now. Nanotechnology is not a new filed, but rather a new perspective in all fields. Our knowledge of the nature considers it as the last scale of the product (Soleimani, 2006).

Many believe that nanotechnology is a new innovation that would take control of the stock exchange market in coming 50 years and improve the life in many ways. But those against it predict disastrous consequences of this technology as wells as environmental destruction and causing social class differences and even racial discrimination. Discussions and differences of opinions are a lot in this respect and event there is a talk about nanotechnology, we cannot make sure whether everyone is talking about the same thing or not. Is nanotechnology a new and converted technology? Is nanotechnology a threat to the world? Or that it should be ignored as an insignificant slogan?

In fact, nanotechnology refers to a knowledge that can make out of every single atom and any type of basic material. Imagine a small submarine that moves through the veins and eliminates cholesterols and renews the neurotic terminals. Therefore, nanotechnology deals with tools that cannot be seen by the unarmed eye. To have a closer look it can be stated that nanotechnology is created in an automatic world where the grass are decorated with microscopic insects or to make bread baker from the atoms and destroy all viruses from the human world by the use of highly minute tools (Jones and wood, 2005). The world is at the threshold of the revolution of a new technology superior to any human experience. This new powerful technological revolution has the capacity to bring health, happiness and education and training without pollution for every human being on the earth planet. Eternity and longevity are the first result of the nanotechnology. Medical nanotechnology ends up the death, senility and fatal diseases. Nanotechnology designs computers that are capable of arranging atoms and molecules in new structures in every second. Along with the development of the nanotechnology the life style of the people gets basically changed and the behaviors of the people get highly affected by this new system. Space travel gets safe and cheap and possible for everyone. Nanotechnology reduces the danger of the living creatures of the world to nil. Consequently, as a result of the development of the nanotechnology all consumer products would be endurable, efficient, cheap and ample. As a result of this technology, many television channels would emerge in this respect and the topics of the magazines and papers with nanotechnology gets started. A macro computer is not larger than a human cell. A space ship would not be more expensive than a four person family car and because of these reasons and many other reasons the life of a human being would basically change. Nanotechnology makes the goods out of useless recycling materials and the experts of nanotechnology make complex robots out of molecular and atomic particle. Nanotechnology by the use of chemical characteristics of atoms and molecules and how the molecules approach each other and get adhesive quality suggest the construction of new molecules that have wonderful characteristics (Ibid).

\subsection{Intellectual Property Rights}

The phrase intellectual rights were first used by the Belgian lawyer Picard in 1899 and some other lawyers instead of that have used the phrases $<$ non-material property $>$, < rights of non-material properties $>$, and $<$ rights of attracting customer> (Ibid). Intellectual property rights refer to the rights brought about by intellectual creations and innovations in terms of science, industry, literature and art through science, art or the innovation of the creator. This group of rights refers to the rights that have economic value and their topic is not a material thing because these rights are the impact of thought. The purpose of protecting these rights is to encourage and persuade intellectual creations and innovations and liberating the access to them by the purpose of economic, social and cultural development and improving the human lifestyle (Noruzi, 2002).

Intellectual property rights have special features that separate it from other types of properties that has two sides of the material and spiritual value and the limitations of protection that are briefly explained in the following part. 


\subsubsection{Material and Spiritual Aspect}

Intellectual property right is the creation of human mind and thought. This fact has caused these properties in addition to having material aspect to get a new aspect that relates them to the creator of them. This dimension is referred as the ethical and spiritual aspect of the Intellectual property rights. Therefore, when we talk about the Intellectual property rights in fact we mean two aspects of it: spiritual right and financial right. The spiritual right represents the personality, credit, and prestige of the creator and reflects the sign of innovation, creation and honesty (on the basis of intellectually created cases). The dependence of this dimension to the personality of the creator causes this right not to be limited to time and place in contrast to the financial dimension and does not have the capacity of being transferred.

Financial right is another aspect and it is the second dimension of the Intellectual property rights of the creator. On the basis of this right in terms of finance the creator has the right to transfer his/her rights to others in return of receiving an amount of money (Mahmudi, 2012).

\subsubsection{Protection Limitation}

Intellectual property associates with limits and restraints special to it and these limitations are the requirements and characteristics of intellectual properties and belongings. One of the significant features of the intellectual property rights as will be discussed later in this study is the time limitation and temporary economic and financial benefit of the intellectual attempts. In other words principally the rights created on the basis of the intellectual property for the owners in an exclusive way are limited to a definite time and the creator can benefit from the financial benefits of the work over the aforesaid period (Khedmat Gozar, 2012). For example the right of utilizing from the invention or the period of protecting the invention is 20 years.

The presence of such characteristic is because of the fact that the society tries to provide the facilities for the transference of knowledge, art and technology and other intellectual processes by breaking the exclusive right of the creator. Similarly, intellectual properties are merely protected in particular geographical lands and territories (Ibid). For example the invention is protected only in the countries where it has been registered.

Therefore, in terms of time and place the intellectual events face limited protections. The imposition of the place limitations, mostly originates from the authoritative considerations of the countries. In other words the states do not want to make their country bereft of the scientific and cultural impact of them by allotting the exclusive right to the respective creators of other countries; but today, by passing the bilateral and multilateral conventions such as Paris and Bern convention and TRIPS agreement and European invention convention has reduced the effect of place limitation and has provided the foundation for trans-boundary protection of the intellectual property rights. However the time and place limitation does not apply to all instances of the intellectual property rights because there is no limitation in terms of unveiled data (technical knowledge and trade secrets). That is the protection of them is not limited to time or place.

Similarly, it should be mentioned that the intellectual property rights is divided into two broad categories: A) industrial and trade property B) literary and artistic property and related rights

\section{A) Industrial and Trade property}

Industrial property is a branch of the intellectual property rights which relates to the intellectual and mental innovations in industrial field. The most important of these innovations are: the patent of invention, trademarks, trade name, industrial designs, trade and service signs, geographic signs, goods' departure sign and preventing deceptive trade competitions. Generally, industrial property forms a set of legal collection whose purpose is that people without any fear of offending from others do their business and industrial activity while they are safe from any offensive from the third persons (Noruzi, 2002).

B) Literary and Artistic property and related rights

The influence of this branch of intellectual creation rights is quite various and depending on the level of development of the countries it varies. But these scattered works and instances might be divided into some general groups: 1- Written and unwritten literary and scientific works including books, essays, artistic works, decorative and acting works, computer works and data sites. 2- Audio record producers' rights 3- Radio and television broadcasting organizations' rights.

\section{Nanotechnology as an Intellectual Property Right}

\subsection{In TRIPS Agreement}

Over the last two decades the role of the intellectual property rights in all areas of science and technology across the world has been quite considerable. First of all this is because of the rules codified by the TRIPS agreement of 
the world trade organization and bilateral and regional conventions that have been codified and diagnosed. The TRIPS agreement urges all member countries of the world trade organization to accept and observe the least requirements of the standards of the intellectual property rights (Agreement on the Trade Related Aspects of intellectual Property Rights, 1994).

On the basis of TRIPS agreement the member countries need to provide the access to the patents of inventions or products and processes in all areas of technology without discrimination and conditioned to the patent standards (novelty, having innovative step, and industrial functionality) (Bowman, 2007). However, during the agreement negotiations, social TRIPS agreement in terms of controversial technology inventions not result was concluded. The United States of America and other developed countries did not approve of any exceptions in terms of patent rights while the developing countries had different views in terms of cases based on the traditional knowledge and demanded for exception in these cases. Article $273 \mathrm{~B}$ of TRIPS agreement is a text about the environmental processes and product on which an agreement was reached. This article states that: <plants and animals and the basically biological processes can be excluded from the patent, although the members of the world trade organization should present protection of plant species either by patents or by an efficient Sui generis system.

Developing countries were allowed until 2000 to codify rules in this respect and the countries with the least rate of development were allowed until 2006 (the transference period was prolonged for them until 2013). From 2013 afterwards, even the countries with the least level of development are required to identify and observe nanotechnology patents by TRIPS of the world trade organization (Shand and Jo Wetter, 2007).

Also, there are cases that in spite of their approval as invention because of the presence of a number of conditions and issues the creator is unable to patent the invention and benefit from its exclusive use and attracting personal benefit. In many of the rules such as European convention the registration of new international and regional agreements such as TRIPS and Europe biotechnical instructions and inventions against the ethics has been recognized as impossible to patent but the concept of ethics and general system in these regulations are very general, vague and interpretable and the patent offices given the ample economic benefits obtained from biotechnical inventions and the trade competitions of the countries with each other in a functional approach interpret these exceptions deficiently. This fact can be inspected in the Europe biotechnical instruction that despite vast arguments that there was through its codification and despite the fact that explicitly had called the patent of inventions against the ethics and general order impossible to patent.

The American state during the codification of the TRIPS emphasized on this outlook and demanded the possibility of registering all types of inventions both products and processes in all technologies, but Europeans, according to EPC asked for the exception of plant and animal species and the basically biologic processes for the plants and animals and the inventions against the general ethics and order and finally a consensus was reached between them so that in the first note of the article 27 any invention both products and processes in all technology areas with the condition of having the requirements of patenting inventions (novelty, innovation and industrial function) was announced as patentable and in part two the members were allowed in order to preserve the general ethics and order refrain from patenting the inventions whose commercial utilization disrupts issues such as life protection, human, plant or animal health, and damaging the environment (Sadeghi, 2006).

Fifth part of the agreement consists of articles 27-34 about the patent of inventions. Part 3 of the article 27 authorizes the members:

A) Diagnostic, treatment, and surgery for the treatment of humans and animals

B) Animals and plants except for microorganisms

C) Basically, biological processes to produce plants or animals make them an exception to patent.

This exception reduces the exclusiveness in terms of health and treatment to the least and it is in accord with the general policy that the modern techniques should be freely distributed and the general people and the world community should use it and expand its use amply. However, such inventions because of the problems in terms of preventing their violation do not have any practical value (Habiba and Motamedi, 2002).

The other exception in the second part of the article 27 is the lack of contrast between patenting invention and trade use cases with general ethics and order, such as protecting life or human and animal health to prevent inflicting serious damage to the environment that shows that if an invention is against the general ethics or harmful to humans and other creatures cannot be approved of. Therefore, according to the part $\angle \mathrm{B}>$ note 3 of the article 27 members of the world trade organization are required to patent the microorganisms and microbiologic processes that is what being used in the biotechnology. Anyway, any type of commitment to the protection of plant species through patenting inventions or via a special protective system or a combination of them that would 
arrange regulations in this respect. However the effective term does not refer that international convention does not protect new plant species (UPOV). Therefore, the states are free to establish their own protective system. By selecting a special protective system the countries can neutralize the increasing protection of law under the convention of biological variety. Besides that the scientific interpretation of the phrase (non-biologic process $>$ can exclude most of the technical inventions about plants and animals from the area of patenting. According to the opinion of many of the scientists most of the biological distribution methods have a biological aspect (Ibid).

The exceptions of patents are explained in the article 53 of the European convention and consist of items mentioned in part (A) < public order> and <ethics > and two unique categories of non-patentable inventions:

1) Plant or animal varieties and biological processes for their production

2) Methods to cure and treat or diagnose applied to human or animal

According to the items mentioned in this part microbiologic processes are excluded from this ruling for the production of plants and animals. But it should be attended that part $\angle \mathrm{B}>$ of the article 53 is independent from the part $<\mathrm{A}>$ that is assigning patentable inventions to plant and animal species in the opinion of the writers of the convention has not been because of their contrasts with the ethics and public order, but it has been because of the animal species and biological processes for their production has not been considered as an appropriate subject matter for patenting the invention. In other words, these cases have been specially excluded from the patenting and the plant varieties on the basis of the special system (Sui gendris) have been protected before the ratification of the EPC on the basis of international convention of protecting new varieties of plants (International Convention for the Protection of New Varieties of Plant"1961") have been protected via a different method (Bently and Sheman, 2001).

In the biotechnical instruction it has been stated that:

$<$ Inventions whose industrial utilization are against $<$ public order $>$ or $<$ ethics $>$ are considered as non-protectable (note 1 of the article 6 ) and instances of these inventions were obtained as follows:

A) Human spirits homogenizing processes

B) Human spirits racial identity modification processes

C) Use of human fetuses for trade and industrial purposes

D) Animal genetic identity modification processes which are harmful for them and also the animals generated through these processes.

Although it seems that the protection of the genetic resources in biologic variety convention is more optimal than that of TRIPS agreement, but from a legal perspective the references made by the states to justify their violations of commitments obtained in TRIPS agreement is difficult because according to the rule in international law the regulations of the earlier agreements are to some extent administrable that are in accord with the no-right convention. ${ }^{2}$ And also on the basis of the priority of the former rule to the latter the rules of TRIPS are undoubtedly more special and detailed that that of convention (CBD) which earlier than that (Sadeghi, 2006).

Because of the difficulty of reaching a consensus, it was agreed that the controversial article of (part 3) article 27 TRIPS in 1999 to be revised and edited. The discussion and argument on the subject of patent of biochemical inventions in world trade organization is about the patents of nanotechnology. This revision did not happen because the materials and processes at nano scale, particularly in cases where the claimed material is either animate or inanimate or both they put forward basic questions (nanotechnology patents). Broad nanotechnology patents have now been issued to enclose different parts of the industry and include survey claims in terms of basic blocks and natural generators. Should the patents be allotted for the basic blocks and natural generators? Does the TRIPS agreement urge all developing countries to recognize and practice the related patents of nano-biotechnology inventions? Does it include the inventions of the basic biological processes of animals and plants? Do total broad patents or the storage in terms of materials, processes and instruments at nano scale would be the references of the Southern states and their cooperation in nano-biotechnology revolution? Over the last decade, some of the countries have warned against the inequalities of the intellectual property rights for the Southern countries to the human rights commission of the United Nations and social and civil movements. Recently even in the world intellectual property rights organization (WIPO) PART OF THE United Nations whose mission is to elevate and protect intellectual property rights has become non-defendable in terms of

\footnotetext{
${ }^{1}$ Part 2 article 6

2 article 30 , part 3 and 2
} 
unequal intellectual property rights and more negative impacts for many of the developing states. In September 2004 Geneva declaration in terms of the future of the world intellectual property rights organization warned that the current regimes have negative impacts on developing countries and lead to lack of access to the basic medicine and anti-competition activities that impede innovation and lack of provision of social and public goods. In the meeting of the general assembly of the 27th of September to 5th of October 2004 WIPO Brazil and Argentina along with 14 developing states suggested WIPO to confirm and ratify the development program:

$<$ Protection of intellectual property rights is an inherent goal and the coordination of intellectual property rights leads to the higher standards of all countries regardless of their developmental level. The role of intellectual property rights and its impact on the development and progress should be carefully and precisely analyzed and examined. Protection of the intellectual property rights acts as a political tool that can generate costs and resources in practice that vary on the basis of the level of the development of a country. Therefore, to guarantee the issue that protecting the intellectual property rights does not lead to higher costs and expenses compared to the advantages all countries should become engaged in this issue.>

The general assembly of WIPO to approve of the development program arranged a guarantee, but the United States of America, England and other industrial countries opposed by referring to the consideration of development within the WIPO and significantly higher cost of it and only insisted on this issue that WIPO should be provided to developing countries with more technical assistance. Despite the running discussions in 2005 and 2006 in terms of the development program, it reached a dead end and it was ended in June 2006 (New and Tove, 2006).

Patent system makes the provision of protection without discrimination for all technologies in all possible areas of technology. Such an issue is stated in the note 1 of the article 27 of the TRIPS agreement under the title of $<$ patentable subject $>$ :

$<$ The right of patenting invention exists for any type of invention either products or the processes in all fields of technology, with the condition that the inventions are novel and innovative with industrial function. Patents will be at hand and the patent rights will be implemented without discrimination. Registration and benefiting from the right of patenting without discrimination in terms of the place of invention, filed of technology, and that the goods are imported or produced in the place.>

The subject of this part was a success obtained by the developed states against the developing states $>$ because more than 50 states of the developing countries in one or more technology fields particularly medical products were not authorized. The officials of the developing countries presented different reasons such as the public hygiene, the expensiveness of medicines and lack of access to the critical drugs that have been discussed over the talks between the North and the South.

Nanotechnology because of its features can be placed within the framework of the patentable agreement of TRIPS therefore in the first place the protective regime of this newly emerged area of technology is at hand. Therefore, in case the requests of patents meet the requirements of novelty, innovativeness (or non-apparent in the law system of the United States) and the industrial function and the public announcement ${ }^{3}$ can be provided and in this case the members of the world trade organization WTO would be prevented from discrimination in terms of protecting nanotechnology inventions on the basis of their national law and should for a period of 20 years from the time of patenting the invention protect the invention and accordingly the article 33 provides the exclusive right for the applicant of registering patent in that country (Dinwoodie et al., 2001).

This is worth mentioning that all applications of nanotechnology and its functions cannot be protected by patents. On the basis of article (1) 27 patents should be available for all inventions and not for absolute explorations. While the TRIPS agreement is incapable of providing a definition of the invention article (1), 27 is an attempt to differentiate between vague discrimination between inventions and discoveries. This differentiation is reinforced by the first generation of nanotechnology products such as carbon nano tubes and Fullere nes. Since these combinations are naturally available the technical identity (1), 27 is an obstacle against the aforementioned products. Bastani and Fernandez (2000) point out that the development of technologies such as nanotechnology leads to the creation of ambiguities in interdisciplinary layers that existed between inventions and discoveries. The elimination of this differentiation and a border line can be showed by the analysis of the possibility of patent of inventions in biotechnology (patents about the life) (Bstani and Fernandez, 2000). In a critical essay of the biotechnical patents within the framework of the TRIPS agreement and European Union technology instruction (passed in 1998), HQ stated that the term (indeterminate) has provided a lot of flexibility for the potential

${ }^{3}$ article 29 of the TRIPS agreement 
researchers and applicants of patent registration in terms of the patentable items and non-patentable ones.

HQ states that patents that are on the basis of absolute explorations despite the lack of fulfilling the criteria requirements of inventions have become registered. These items include the discovery of human cells, such the umbilical cord cells, plant genes such as the sequence of the rice genome and medical cloning and methods of separating stem cells. This topic is extracted from this interpretation that processes that lead to such explorations are beyond the spirit of the TRIPS agreement and therefore they are non-patentable (HO, 2002).

The reflection of this issue on the obtained achievements in the biotechnology industry makes this deduction possible that the changes in technology have lead to the development of the filed of patent international law. In this case such a differentiation because of its role in determining the realm and expansion of the subject of patentable is of significant importance. Etc group expressed their opposition that the expansive patents that are allotted in terms of nanotechnology inventions connect different parts of the industry together and include survey claims on all levels of the periodic table. By the emergence of the second and third nanotechnology generation Etc groups stated that the possibility of patenting basic and fundamental materials at nano scale can exclude the basic elements that principally life and creation is possible on the basis of them (Etc, 2005).

It is possible that convergence and nearness of the nanotechnology and biotechnology in a short period of time make the subject of patentable more complicated and over time and development of technology the convergence of nanotechnology and biotechnology can urge the policy makers to create a special patent regime (Sui generis) for the nano-biotechnology. Creating a special quasi-patent format without considering the regime of $<$ plant varieties law $>$ (Lesser, 2000) would be possible and would approve of the excellent identity and characteristics of inherent manipulation of the animate organisms with atomic precision. This option provides a middle road in between the present framework of the international intellectual property rights passed by the TRIPS. Besides that, it considers the time of encouraging innovation, which is one of the main goals of the patent system without inflicting any damage in broader goals that have been promised by the contemporary technology.

\subsection{The Convention on Biological Diversity}

The convention on biological diversity is considered as part of the environmental area and development process of the United Nations organization conference. The convention on biological diversity is an interstate agreement which was signed in 1992 in Rio De Janiro and was obligatory in 1993 and so far more than 190 states have joined to this convention.

Islamic Republic of Iran officially joined this convention in 1996 and acted upon the determination of the approaches and national action program in terms of protecting the biological diversity that is one of the requirements of joining this treaty. This treaty covers a long range of issues related to the biological diversity such as biological diversity of the jungles, seas and beaches, dry and semi-dry lands, internal waters, islands and mountainous areas, and agricultural biological diversity, protected areas, foreign attacking varieties, facilitating access to genetic resources and sharing the obtained benefits from it, world innovation of ranking the species, consistent use of the biological diversity, etc. The goals of the convention on biological diversity include: protecting the biological diversity, consistent use of the biological diversity resources, equal and fair facilitation of the access to the benefits obtained from utilizing genetic resources.

In contrast to the earlier passed treaties that considered the protection of special varieties and habitats in the convention on biological diversity it has been stated that ecosystems, varieties and genes should in line with the provision of the human benefits without causing the reduction in biological diversity in the long term should be implemented. Some of the main issues that have been discussed in the convention are as follows:

1- Assigning encouragements for consistent protection and utility of the biological diversity

2- Consistent access to the genetic resources

3- Access to the technology and its transference such as biotechnology

4- Technical and scientific cooperation

5- Assessment of the environmental influences

6- Education and enlightenment

7- Provision of financial resources

8- Presenting the national report in terms of performed activities in line with fulfilling commitments

This convention has emphasized on the right of the place of occurrence of genetic and biological resources and the contracting party would take measures that as a result of patenting the invention and other intellectual 
property rights about the genetic resources, access to the technology, and its transference become facilitated. In the convention on biological diversity CBD the contracting states are authorized to determined the conditions of access to the genetic resources themselves $<$ on the basis of the agreed condition between the sides $>$ but no system has be predicted to arrange the activities concerning the use of biological resources. The regulations concerning the equal sharing of the benefits have been stated in a general way and no coherent system has been codified for this issue that weakens the position of the poor countries to a large extent.

Part 1 of the article 16 in the convention on biological diversity in terms of access to the technology and transference of it among the member countries are the main elements of reaching the goals of this convention on the basis of the contents of this article the member countries are required to provide the necessary facilities for the access and transference of the technologies about consistent protection of the biological diversity by the use of genetic resources and do not inflict considerable damage to the environment for other member countries (Habibi and Motamedi, 2002). The access to the aforesaid technology in part 1 and its transference to the developing countries should be under fair and optimal conditions as preferred and allotted by the contracting bilateral sides if necessary in accordance with the determined sequence predicted in articles 20 and 21 to be facilitated and provided. In cases where the technology items are under patent or other intellectual property rights the access and the transference would be in accord with the aforementioned conditions and requirements with apposite protection commensurate with the intellectual property rights. ${ }^{4}$

Each of the member countries should take administrative and policy making measures with this purpose that the member countries, particularly the developing countries that are the main providers of the genetic resources on the basis of the agreed condition between two sides to have access to the technology and its transferences on the basis of the patent right and other intellectual property rights or if necessary by enacting the contents of the articles items 20 and 21 and on the basis of the international law and in line with parts 4 and 5 of the article 16 to be protected.

Parts 4 and 5 of the article 16 state that: each of the member states should facilitate the process in an opposite way by taking legislative, administrative and policy making measures with the purpose of providing access to the technology to the private sector, its common development and the transference of the aforesaid technology in part 1 to the benefit of the state institutions and private sectors of the developing countries.

The member countries by approving of the fact that this patent right and other intellectual property rights can be influential in practicing this convention need to act in accord with the local rules and international law to make sure that this law protects this convention and is not in contrast with its goals.

\section{Nanotechnology Development and Transference, Third World Countries and the TRIPS Agreement}

The right of development and the intellectual property rights are both considered as instances of the human rights. But to fulfill these two rights there are contrasts in practice that by considering the corresponding principles for each of them to determine the expansion of them and moderate them. If the development right is considered as a natural individual right and one of the requirements of life right and the intellectual property right as an advantage allotted by the society to the creator of the intellectual product we can moderate the intellectual property right in accord with the development right of the individuals. These contradictions and the type of their differences have led to vast challenges among the developing and less developed countries. So that the developed countries have emphasized on the further support of the intellectual property rights, but the developing countries argue that the further support of the intellectual property rights disrupts their fulfillment of the development right. Within the framework of the world trade organization the TRIPS agreement has presented a solution to settle this problem and has considered a number of commitments for the member countries. But even after the ratification of this agreement the contradictions proceeded in particular in the areas such as the transference of the technology and the public health became more conspicuous. To solve these differences, some solutions have been put forward that some of them have been effective to some extent. Among the solutions that the developing countries should consider are enhancing the local technical capacities, establishing more efficient and practical international rules and regulations, encouraging direct foreign investments, use of complementary systems such as training human resources and efficient and expert forces, reinforcing infra structures and local markets. However the contradictions among the developed and the developing countries continue to exist and the international attempts in this respect are ongoing (Zeinoddini, 2008).

To prevent unequal trade the protection of the intellectual property rights is an essential thought. However, in codifying and administering the international regimes a practical reality needs to be considered: unequal

\footnotetext{
${ }^{4}$ Part 1 and 2 of the article 16 , convention on the biological diversity
} 
distribution of the intellectual property rights and the consequences of that, for example the developed countries have registered $90 \%$ of the patents of inventions to them. Given this inequality in any sequence taken at international level in terms of the intellectual property rights the necessity of supporting this right as a type of preferential behavior in developing countries should be included so that these countries do not experience unbearable expenses and in long term they can adapt themselves to these standards. Given these considerations, the TRIPS agreement in addition to determining minimum standards for the protection of the intellectual property rights allotted special points for the developing countries and less developed countries (LDCS) to create a type of equilibrium between the intellectual property rights of the creators and the users of these rights and it seems that the developing countries need to try more in the coming talks of the world trade organization to enhance their goals.

In the preface of the agreement $<$ the confirmation of the special needs of the less developed countries to benefit from the maximum flexibility to administer the internal rules and regulations to enable them to establish an opposite and reliable technologic basis has been mentioned $><$ the significance of reducing the tensions by accepting strong commitments to settle the differences in terms of the intellectual property rights issues by implementing multilateral methods have been emphasized. Therefore, in the same preface to the aforementioned agreement the necessity of considering the development of less developed countries and applying multilateral methods have been emphasized (Bozorgi, 2001).

In article 7 as the most significant goal of the agreement it has been asserted that: <protecting the intellectual property rights and administration of these rights should assist the development of innovative technologies and the transference of the technology and the mutual use of the producers as well as the users so that lead to an economic and social welfare equilibrium of the rights and the commitments $>$ On the basis of this article the development and transference of technology and the equilibrium between the rights and commitments should be considered as the main goals of the agreement and all other contents of the article should be looked at from this vantage point. In article 8 that states the principles of the agreement on one hand in the first part taking the required measures <preserving the hygiene and nutrition and also the expansion of the public benefits in critical parts have vital significance for the social, economic and technologic development under the condition they are in accord with the rules of the agreement> are allowed and on the other hand in part two the necessity of preventing misuse of the owners of the intellectual property rights: <in order to prevent the misuse of the owners of the intellectual property right of this right and refraining from the ways that unreasonable limit the trade or leave negative impact on the transference of the technology, it is possible that taking the required measure commensurate with the coordination and coherence with the rules of the present agreement be necessary $>$ In fact, articles 7 and 8 determine the general framework of the agreement and other parts of the agreement should be interpreted on the basis of them.

In items 25 and 26 the possibility of creating an exceptional protection of industrial plans has been authorized. Article 27 also authorized the exclusion of some of the inventions of the patent right in case <prevention> commercial use of them within their realm interrupts the ethical or public order such as preserving life or hygiene of human, animal or plant to avoid serious damage to the environment> (second part). In the third part of that article the possibility of excluding the following items from the right of patent can be referred (Soltani, 2010).

A) Diagnosis, treatment and surgery methods to cure humans and animals;

B) Plants and animals except for the microorganisms and basically biologic processes to produce plants or animals outside biological processes and microbiology. Besides that in the second part of note three also doing revisions in this part that is four years after the date of the world trade organization agreement have been mentioned. In article 30 there has been a reference to the possibility of creating an exception to the right of invention.

In article 31 the compulsory issuing of the right certificate for the use of any invention with the reference to the following issues has been authorized:

Lack of the agreement of the owner of the invention with allotting the right certificate with rational trade conditions, public benefits, and emergency conditions and non-trade use and utilizing the second invention (parts $<\mathrm{B}>$ and $<\mathrm{C}>$ ) in item 2 of the article 37 also refers to the possibility of issuing compulsory certificate in terms of the plans to construct integral circles. On the basis of these articles the transference of the technology and prevention of imposing unequal conditions in allotting certificates from the owners of the inventions and the construction plans can be facilitated.

In article 40 also after referring to the limiting procedure of competition and the transference of the technology, it 
is asserted that the members can in order to control or prevent those <ways or conditions of issuing the certificate that in special cases are likely lead to misuse of the intellectual property rights and have negative impact on the competition in the market $>$ take the required measures and rules (first and second part) according to the articles 60 and 61 also the violation of $<$ trade scale $>$ is considered as forbidden or the small cargos without trade identity are excluded from the administration of TRIPS agreement.

In article 65 one year to the developed countries and five years to the developing countries were allowed to administer the TRIPS agreement and the possibility of extending the time of developing countries to five years in terms of protecting the right of inventing products and not processes have been referred parts 1,2,3, in article 66 also refers to $<$ the needs and special conditions of the member less developed countries, economic, financial and official limitations of them in these countries and the provision of a flexible approach to create a consistent technology basis $>$ longer respite was allotted to them, i.e. 11 years and the extension of this period has also been recognized as authorized (first part). In the second part of the article 66 also the necessity of the cooperation of the developed countries in transferring the technology to the less developed countries has been mentioned. The developed and less developed countries should make the most use of the present respite and if necessary try to prolong this period.

But the developing countries in order to change the rules and regulations and creating a foundation to administer the TRIPS agreement apart from the allotted respite should have access to the required resources. In this case in article 67 of the agreement the cooperation of the developed countries in providing the educational, technical and financial assistance to the developing and less developed countries in order to administer the agreement has been mentioned that these countries can depend on (Bozorgi, 2001).

In the article 76 of the agreement it has explicitly asserted that nothing would be interpreted in these items so that harm the political benefits of any member country and finally in the article 71 there is a prediction of the possibility of the revision of the TRIPS agreement on the basis of the new conditions and changes that occur in the developing and less developed countries in the future negotiations and try to orient this agreement towards their legal benefits and considerations (Ibid).

\section{Conclusion}

On the basis of what was presented and given the newly emerged nanotechnology the talk of the need for new patent law is reasonable. However the increasing number of the issued demands for issuing patents related to nano over the last years clearly shows the acceptance of nanotechnology within the patent law. However, it needs to be considered that when the science of law develops side by side and along with the other fields of human knowledge and since the absolute justice cannot be administered as the general rule in all cases and given the fact that multiple feature of the additional rules and regulations are not optimal and an equilibrium need to be achieved then:

The presence of a special legal regime would only be felt that a particular case cannot be interpreted on the basis of the general rules. Despite that the application and enforcement of the present patent law and the subject law on the new technologies have never been a clear cult issue without challenges. The newly emerged nanotechnology the same as most of the technologies is based on a number of basic inventions. At the same time with the development of the industry the companies with nanotechnology right certificates would use them to preserve their products and at the same time with the coming benefits of the offering their products the legal cases that are a sign of confusion and puzzlement would emerge. Strong support of the inventions can lead to the confusion in terms of inventions that is an extra cost upon the technological development because of the legal suits in order to defend the right of the registered patents of invention the limited right of registering patents of invention through exclusive and concentrated right of patenting in a single institute in a limited way is a step towards creating further limitation and exclusion. In case a company prior to obtain the required capital for the development of technology and have to transfer the original right of invention, it is evident that other companies would be incited to accelerate the developmental measures in that particular technology case. The required time to impose obligations in terms of transferring the certificate of non-exclusive right is the time the produced products on the basis of the original invention enter the market. The owner of the basic invention receives a significant benefit from the sale of the products and the right of invention for the transference of the legal right of the basic technology. The other companies would benefit from the sale of the products that did not benefit the original owner who personally did not have the possibility of producing and entering the market. However the non-exclusive assignment of the right of the inventions can serve as a key factor to develop the technology field.

\section{References}

Agreement on the Trade Related Aspects of intellectual Property Rights. (1994). See: UNCTAD/ICTSD 
Cavpacity Building Project on Intellectual property Rights and Sustainable Devalopment, TRIPS and Development: Resource Book (December 2002), Part TWO: Substantive Obligations, 2.5 Patents, UNCTAD.

Bastani, F. (2000). Intellectual property rights in nanotechnology, Menlo Park. C.A. Fernandez \& Associates. LLPL. Retrieved from http//.www. iploft .com/Nanotechnology .pdf

Bently, L., \& Sheman, B. (2001). Oxford University Press, Intellectual Property Law. p.395-396.

Bowman, D. M. (2007). Technology insociety, Patently obvious: Intellectual Property Rights and Nanotechnology, 29(3), 310.

Bozorgi, V. (2001). world trade organization, intellectual property rights of the developing countries economic and political data, No 173-174, P192-197.

Dinwoodie, H. P. (2001). International intellectual property law and policy Newark, NJ. LexisNexis.

Etc Group. (2005). Nanotech, second Nature, Patents: Implications for the Global south, Winnipeg, Manitoba., Action Group on Erosion, Technology and Concentration.

Habiba, S., \& Motamedi, G. (2002). Tehran University of political sciences and law faculty protecting traditional knowledge in national and international scene, No.74, P.165.

HO, M. (2002). Why biotech patents are patently absurd. journal of Intellectual Property Rihts, 7, 151- 165.

Jones, R., \& Wood, S. (2005). Technology: Nanotechnology, translated by the research chamber of Iran trade chamber magazine, (432), 43.

Kalantari Meibodi, E. (2014). the position of intellectual property law within the nanotechnology, M.A. thesis Payame nur Tehran, p.32.

Khedmat Gozar, M. (2012). Intellectual property philosophy (2nd ed.). Mizan publication, Tehran. P.221.

Lesser, W. (2000). an economic approach to identifying an, effective sui Genris system, for plant protection under $\quad$ TRIPS, https://doi.org/10.1002/(SICI)1520-6297(200024)16:1<96::AID-AGR8>3.0.CO;2-F

Mahmudi, A. (2012). the identity of intellectual property rights position and its place in property law research and science seasonal of civil rights Mizan Publication, Tehran, P.221.

New, W., \& Tove, G. I. (2006). Intellectual Property Watch, WIPO Development Agenda Talks End with No Agreement for Now. 97-113.

Noruzi, A. (2002). intellectual property rights (writer right and industrial property) Chapar publications, Tehran, P.19-20.

Sadeghi, M. (2006, Autumn). ethical challenges of registering biotechnical inventions, No.40, P.104.

Shahmohammadi, M. (2014). religious jurisprudence and legal analysis of the nanotechnology, M.A. thesis non-benficiary institute.

Shand, H., \& Jo Wetter, K. (2007). Trends in Intellectual Property and Nanotechnology: Implications for the Global South. Journal of Intellectual Property Rights, 12.

Soleimani, J. (2006). nanotechnology in simple words. technology and science book magazine, 86, 57.

Soltani, M. (2010). the nanotechnology ownership and legal issues at different times, seasonal automotive nanotechnology, P20-21.

The Convention on Biological Diversity"1992."

Van calster, G. (2006, September). Regulationg Nanotechnology in the European Union. Nanotechnology Law \& Business, 356-372.

Zeinoddini, F. (2008). development right ratio within the international law and observing the intellectual property rights within the world trade organization M.A thesis Tehran University law and political sciences public law department, human rights.

\section{Copyrights}

Copyright for this article is retained by the author(s), with first publication rights granted to the journal.

This is an open-access article distributed under the terms and conditions of the Creative Commons Attribution license (http://creativecommons.org/licenses/by/4.0/). 